\title{
Pathogenic fungus in feral populations of the invasive North American bullfrog in Argentina
}

\author{
Romina Ghirardi 1,"*, Javier A. López ${ }^{1,2}$, Eduardo A. Sanabria ${ }^{3,4}$, \\ Lorena B. Quiroga ${ }^{3} \&$ Michael G. Levy ${ }^{5}$ \\ ${ }^{1}$ Instituto Nacional de Limnología, UNL-CONICET. Ciudad Universitaria, \\ Paraje El Pozo, (3000) Santa Fe, Argentina. \\ ${ }^{2}$ Departamento de Ciencias Naturales. Facultad de Humanidades y Ciencias, UNL. \\ Ciudad Universitaria, Paraje El Pozo, (3000) Santa Fe, Argentina. \\ ${ }^{3}$ Instituto de Ciencias Básicas. Facultad de Filosofía, Humanidades y Artes, Universidad Nacional de \\ San Juan, San Juan, Argentina, CP 5400. CONICET. \\ ${ }^{4}$ Facultad de Ciencias Exactas y Naturales, Universidad Nacional de Cuyo, \\ Padre Contreras 1300 (5500) Mendoza. \\ ${ }^{5}$ Department of Population Health and Pathobiology, North Carolina State University, \\ College of Veterinary Medicine, 27607, North Carolina, USA. \\ ${ }^{*}$ Corresponding author: romighirardi@yahoo.com.ar
}

Ghirardi R., López J.A., Sanabria E.A., Quiroga L.B. \& Levy M.G. 2017. Pathogenic fungus in feral populations of the invasive North American bullfrog in Argentina. Belgian Journal of Zoology 147 (2): 81-86. https://doi. org/10.26496/bjz.2017.7

KEYWORDS. Bullfrogs, invasion, emerging infectious diseases.

Nearly a third (32.4\%) of the world's amphibian species are either threatened with extinction or already extinct (1). The chytrid fungus Batrachochytrium dendrobatidis ( $B d)$ (Chytridiomycetes: Ryzophydiales) (2) has been recognized as responsible for mass mortalities or population extinctions of numerous anuran species in different continents (e.g., 3,4,5 and citations therein). There is evidence that legal and illegal trade in amphibians as pets, food and for bio-control is one of the reasons for the spread of $B d(6,7,8,9)$.

The North American bullfrog, Lithobates catesbeianus (Shaw, 1802) (Anura: Ranidae), has been introduced accidentally or intentionally for aquaculture into numerous countries (10). L. catesbeianus is a highly invasive species that disperses rapidly within an ecosystem (11). The oldest report of specimens of $L$. catesbeianus parasitized by $B d$ dates from 1928, and corresponds to individuals from the State of California, USA (12). Bullfrogs can be asymptomatically infected with $B d$ (13), and infected specimens can readily spread the disease into new geographic regions (14).

Initial unsuccessful attempts to introduce bullfrogs into Argentina for farming date from 1935. A subsequent successful introduction occurred during the 1980s $(10,15)$. Escaped individuals became established and the species spread rapidly (16). Nevertheless assessments of the presence of $B d$ in feral bullfrogs from Argentina are lacking $(17,18)$. 
Of 179 amphibian species known in Argentina, 29.14\% are considered threatened (19). The potential impact of $B d$ dispersed by invasive bullfrogs to the Argentine amphibians is large. The aim of this study was to assess the presence of $B d$ in feral populations of $L$. catesbeianus established in the western highlands of Argentina.

We sampled bullfrogs from three feral populations in permanent water bodies in the Argentinean western highlands [phytogeographical region of Monte Province, Chacoan Domain; (20)] (Fig. 1 and Table 1). Sampling took place in a rainy month with high activity of Lithobates catesbeianus (February 2008, February 2010 and February 2011). To capture bullfrogs, we used visual transects and sampling effort standardized by search time (the first two hours after sunset). Amphibians were caught by hand and handled using latex rubber examination gloves. Following HYATT et al. (21) and LIVO (22), we gently but firmly swabbed 10 times on the ventral surface, hind limbs and interdigital membrane of each specimen collected and placed each swab in an individually numbered plastic cryogenic vial, frozen at $-18^{\circ} \mathrm{C}$ for storage. We followed field sampling protocols of DAPTF Fieldwork Code of Practice and those outlined in LIVO (22) to avoid possible cross-contamination of pathogens among ponds.

Laboratory detection and quantification of infection with $B d$ were performed at the Laboratory of Vector Borne Disease Diagnostics from North Carolina State Universitys' School of Veterinary Medicine, using $B d$-specific real-time Taqman (Applied Biosystems, Foster City, CA) quantitative polymerase chain reaction (qPCR), according to the method of BOYLE et al. (23) with PrepMan Ultra Kit (Applied

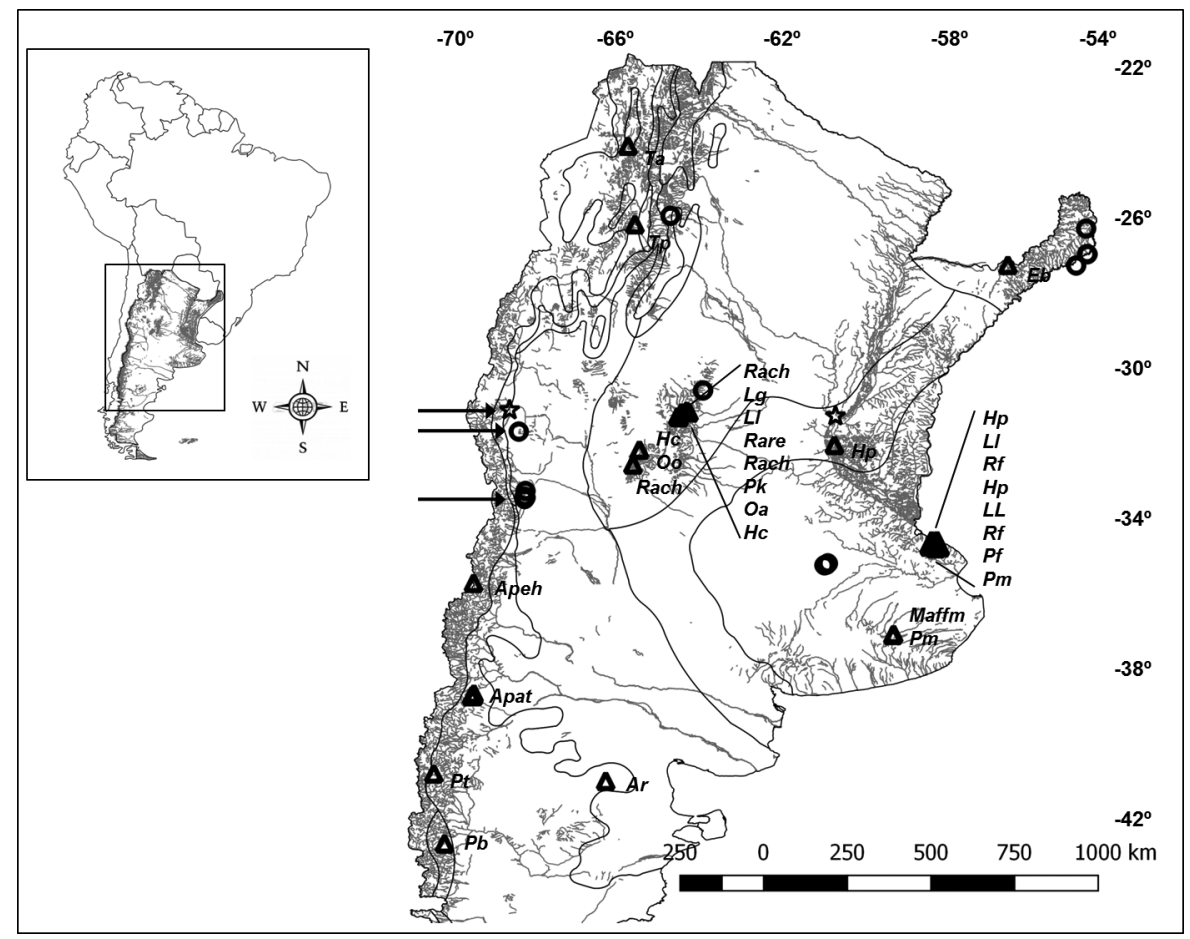

Figure 1. - Chytrid fungus and Lithobates catesbeianus (Shaw, 1802) $(L c)$ reports in Argentina. Arrows: sampled Lithobates catesbeianus populations tested for Batrachochytrium dendrobatidis $(B d)$ for this work. Stars: L. catesbeianus $B d$ positive. Circles: feral populations of $L c$ reported in literature. Triangles: native species infected with $B d$ reported in literature. Species acronyms: (Apeh) Alsodes pehuenche; (Apat) Atelognathus patagonicus; (Ar) A. reverberii;(Eb) Elachistocleis bicolor; (Hc) Hypsiboas cordobae; $(H p) H$. pulchellus; (Lg) Leptodactylus gracilis; (Ll) L. latrans; (Maffm) Melanophryniscus aff. montevidiensis; $(\mathrm{Oo})$ Odontophrynus occidentalis; $(\mathrm{Oa})$ O. achalensis; $(P f)$ Physalaemus fernandezae; (Pb) Pleurodema bufoninum; (Pk) P. kriegi; (Pt) P. thaul; (Pm) Pseudis minutus; (Rach) Rhinella achalensis; (Rare) R. arenarum; (Rf) R. fernandezae; (Tp) Telmatobius pisanoi; (Ta) T. atacamensis. 


\section{TABLE 1}

Lithobates catesbeianus infected with Batrachochytrium dendrobatidis $(B d)$ in sampled localities. Elevation are in $\mathrm{m}$ asl. $\mathrm{N} / B d+$ : total analyzed individuals over number of specimens infected with $B d$. $\mathrm{Ct}$ : cycle threshold of positive individuals.

\begin{tabular}{ccccc}
\hline Locality & Coordinate & Elevation & N/Bd+ & Ct \\
\hline Puchuzúm & $31^{\circ} 20^{\prime} \mathrm{S} ; 69^{\circ} 50^{\prime} \mathrm{O}$ & $\approx 1800$ & $82 / 12$ & $38.24 \pm 3.43$ \\
Cerro Blanco & $31^{\circ} 55^{\prime} \mathrm{S} ; 68^{\circ} 70^{\prime} \mathrm{O}$ & 650 & $10 / 0$ & \\
Capiz & $\approx 33^{\circ} 41^{\prime} \mathrm{S} ; 69^{\circ} 01^{\prime} \mathrm{O}$ & 902 & $11 / 0$ & \\
\hline
\end{tabular}

Biosystems, California, USA). Appropriate negative and positive controls were run concurrently with survey samples, and the limit of detection was less than/equal to 0.5 zoospore equivalents. We analysed the cycle threshold of positive results.

We examined 103 individuals of which 12 tested positive for $B d$. The cycle threshold was $38.24 \pm 3.42$ (Table 1). All infected bullfrogs belonged to only one of the three sampled localities (12 Bd-positive from 82 individuals sampled at Puchuzúm) (Table 1 and Fig. 1). When collected, frogs showed no evident signs of chytridiomycosis to the naked eye. No unusual sloughing of the skin or sliminess was observed in any individual swabbed, nor were any dead individuals recorded during the course of this study.

The most extensive biological invasions of the North American bullfrog into South America are in Brazil and Argentina, with feral populations identified over a large extent of their territories $(24,25,16)$. Until now, the only other work that has looked into $B d$ infection of feral bullfrogs in central Argentina did not detect chytrid (25 specimens examined histologically) (17). Our results confirmed the presence of $B d$ in feral bullfrogs from western Argentina.

Experimental data show that $L$. catesbeianus is among the species capable of being infected by $B d$ without progression of clinical signs or death $(13,26)$. The infected individuals analyzed in this study showed no evident signs of chytridiomycosis, supporting the findings of DASZAK et al. (13) and ESKEW et al. (26). Although the cycle threshold for positive results indicated moderate to minimal amounts of $B d$ DNA in the samples (23), bullfrogs become reservoirs and potential vectors of $B d$ to native cohabitant species.

The first detection of chytridiomycosis in native anuran species from Argentina was reported by HERRERA et al. (27). Since then, specimens in this country belonging to more than 20 native anuran species have been found to be infected (Fig. 1). However, to confirm that introduced bullfrogs are $B d$ vectors to Argentinean native species, the genetics of $B d$ strains should be analyzed to help discriminate among the possible origins and directions of transmission. Furthermore, the number of wild and captive bullfrog populations (and individuals) analyzed should be increased.

Humans are believed to be a major dispersal agent for $B d(3,28)$ and responsible for exotic species introduction and spread (7). Through informal interviews during fieldwork, local people told us that direct dispersion of bullfrog larvae by human translocation to new water bodies is carried out, in order to increase the bullfrog population in nearby areas, since frogs are used as food, live bait for fishing, and for ritual purposes. This activity may favour dispersion of bullfrogs infected by $B d$ to $B d$-free locations.

This is the first study that identifies the presence of $B d$ in feral populations of $L$. catesbeianus in Argentina; this presence represents a major potential threat to native amphibian species. Sampling more specimens 
from the other two locations, Capiz and Cerro Blanco, would contribute to elucidating whether these populations are $B d$ free or if our sampling effort was insufficient for detecting chytrid fungus infection. Strict regulations on the transportation and farm breeding of bullfrogs should be implemented to prevent potential spread of $B d$ by L. catesbeianus. Testing the prevalence of infections in bullfrogs, and monitoring their trade and releases, would further contribute to understanding the role of the commercial trade in the dispersion of pathogens in ecosystems (29).

\section{ACKNOWLEDGEMENTS}

We thank Valeria Corbalán for her assistance in the field work in Mendoza. This study was supported by CONICET to RG, JAL, EAS and LBQ, and PICT 2013-2578.

\section{REFERENCES}

1. IUCN (2016). International Union for Conservation Nature red list. Available from http://www. iucnredlist.org/initiatives/amphibians/ [accessed 26 June 2017].

2. Letcher P.M., Powell M.J., Churchill P.F. \& Chambers J.G. (2006). Ultrastructural and molecular phylogenetic delineation of a new order, the Rhizophydiales (Chytridiomycota). Mycological Research 110: 898-915. https://doi.org/10.1016/j.mycres.2006.06.011

3. Skerratt L.F., Berger L., Speare R., Cashins S., McDonald K.R., Phillott A.D., Hines H.B. \& KENYON N. (2007). Spread of chytridiomycosis has caused the rapid global decline and extinction of frogs. EcoHealth 4: 125-134. https://doi.org/10.1007/s10393-007-0093-5

4. Kilpatrick A.M., Briggs C.J. \& DASZAK P. (2010). The ecology and impact of chytridiomycosis: an emerging disease of amphibians. Trends in Ecology and Evolution 25: 109-118. https://doi. org/10.1016/j.tree.2009.07.011

5. EsKew E.A. \& TODD B.D. (2013). Parallels in amphibian and bat declines from pathogenic fungi. Emerging Infectious Diseases 19: 379-385. https://doi.org/10.3201/eid1903.120707

6. FISHER M.C. \& GARNER T.W.J. (2007). The relationship between the introduction of Batrachochytrium dendrobatidis, the international trade in amphibians and introduced amphibian species. Fungal Biology Reviews 21: 2-9. https://doi.org/10.1016/j.fbr.2007.02.002

7. Pistoni J. \& Toledo L.F. (2010). Amphibian illegal trade in Brazil: what do we know? South American Journal of Herpetology 5: 51-56. https://doi.org/10.2994/057.005.0106

8. Schloegel L.M., Toledo L.F., LongCore J.E., GreEnSPAn S.E., Vieira C.A., LeE M., Zhao S., Wangen C., Ferreira C.M., Hipolito M., Davies A.J., CuOmo C.A., Daszak P. \& James T.Y. (2012). Novel, panzootic and hybrid genotypes of amphibian chytridiomycosis associated with the bullfrog trade. Molecular Ecology 21: 5162-5177. https://doi.org/10.1111/j.1365294X.2012.05710.x

9. Kolby J.E., Smith K.M., Berger L., Karesh W.B., Preston A., Pessier A.P. \& Skerratt L.F. (2014). First evidence of amphibian chytrid fungus (Batrachochytrium dendrobatidis) and ranavirus in Hong Kong amphibian trade. PLOS ONE 9 (3): e90750. https://doi.org/10.1371/journal. pone. 0090750

10. Laufer G., Canavero A., Nuñez D. \& Maneyro R. (2008). Bullfrog (Lithobates catesbeianus) invasion in Uruguay. Biological Invasions 10: 1183-1189. https://doi.org/10.1007/s10530-0079178-x

11. Descamps S. \& De Vocht A. (2016) Movements and habitat use of the invasive species Lithobates catesbeianus in the valley of the Grote Nete (Belgium). Belgian Journal of Zoology 146 (2): 90100. 
GHIRARDI R. et al., Bullfrogs, invasion, emerging infectious diseases

12. Huss M., Huntley L., Vredenburg V., Johns J. \& Green S. (2014). Prevalence of Batrachochytrium dendrobatidis in 120 archived specimens of Lithobates catesbeianus (American Bullfrog) collected in California, 1924-2007. EcoHealth 10 (4): 339-343. https://doi.org/10.1007/ s10393-013-0895-6

13. Daszak P., Strieby A., Cunningham A.A., LongCore J.E., Brown C.C. \& Porter D. (2004). Experimental evidence that the bullfrog (Rana catesbeiana) is a potential carrier of chytridiomycosis, an emerging fungal disease of amphibians. Herpetological Journal 14: 201-207.

14. Mazzoni R., Cunningham A.A., Daszak P., Apolo A., Perdomo E. \& Speranza G. (2003). Emerging pathogen of amphibians in frogs (Rana catesbeiana) farmed for international trade. Emerging Infectious Diseases 9: 995-998. https://doi.org/10.3201/eid0908.030030

15. Luchini L. (1995). Situación de la ranicultura en la República Argentina. Technofrog 95: 3-14.

16. Nori J., Urbina-CARdOna J.N., Loyola R.D., LESCANO J.N. \& LEYNAUd G.C. (2011). Climate change and American bullfrog invasion: What could we expect in South America. Plos One 6 (10): e25718 https://doi.org/10.1371/journal.pone.0025718

17. Barrasso D.A., CAJAde R., Nenda S.J., Baloriani G. \& Herrera R. (2009). Introduction of the American bullfrog Lithobates catesbeianus (Anura: Ranidae) in natural and modified environments: an increasing conservation problem in Argentina. South American Journal of Herpetology 4: 69-75. https://doi.org/10.2994/057.004.0109

18. Ghirardi R., López J.A., Scarabotti P.A., Steciow M.M. \& Perotti M.G. (2011). First record of the chytrid fungus in Lithobates catesbeianus from Argentina: exotic species and conservation. Revista Mexicana de Biodiversidad 82: 1337-1339.

19. Vaira M., Akmentins M.S., Attademo A.M., Baldo D., Barrasso D., Barrionuevo J.S., Basso N., Blotto B., Cairo S., Cajade R., Céspedez J., Corbalán V., Chilote P., Duré M., Falcione C., Ferraro D.P., Gutierrez F.R., Junges P., Lajmanovich R.C., Lescano J.N., Marangoni F., Martinazzo L., Marti L., Moreno L., Natale G.S., Pérez-Iglesias J., Peltzer P.M., Quiroga L.B., Rosset S., SAnabria E.A., SÁnchez P., Schaefer E., Úbeda C. \& ZARACHO V. (2012). Categorización del estado de conservación de los anfibios de la República Argentina. Cuadernos de Herpetología 26 (Supl.1): 131-159. Available from http://sedici.unlp.edu. ar/handle/10915/25469 [accessed 26 June 2017].

20. CABRERA A.L. (1976). Regiones fitogeográficas argentinas. ACME, Buenos Aires.

21. Hyatt A.D., Boyle D.G., Olsen V., Boyle D.B., Berger L., Obendorf D., Dalton A., Kriger K.M., Hero J.M., Hines H., Phillott A.D., CAMPbell R., Marantelli G., Gleason F.H. \& Colling A. (2007). Diagnostic assays and sampling protocols for the detection of Batrachochytrium dendrobatidis. Diseases of Aquatic Organisms 73: 175-192. https://doi. org/10.3354/dao073175

22. LIVo L.J. (2004). Methods for obtaining Batrachochytrium dendrobatidis (Bd) samples for PCR testing. Department of Integrative Physiology, University of Colorado, Boulder, Colorado.

23. Boyle D.G., Boyle V., Olsen J.A., Morgan J.A. \& Hyatt A.D. (2004). Rapid quantitative detection of chytriodiomycosis (Batrachochytrium dendrobatidis) in amphibian samples using realtime PCR assay. Diseases of Aquatic Organisms 60: 133-139. https://doi.org/10.3354/dao060141

24. AKMENTIS M.S. \& CARDOZO D.E. (2010). American bullfrog Lithobates catesbeianus (Shaw, 1802) invasion in Argentina. Biological Invasions 12: 735-737. https://doi.org/10.1007/s10530-009-9515-3

25. Both C., Lingnau R., Santos-Jr. A., Madalozzo B., Pedrosa lima L. \& Grant T. (2011). Widespread Occurrence of the American Bullfrog Lithobates catesbeianus (Shaw, 1802) (Anura: Ranidae), in Brazil. South American Journal of Herpetology 6 (2): 127-134. https://doi. org/10.2994/057.006.0203 
26. EsKew E.A., Worth S.J., Foley J.E. \& TodD B.D. (2015). American bullfrogs (Lithobates catesbeianus) resist infection by multiple isolates of Batrachochytrium dendrobatidis, including one implicated in wild mass mortality. EcoHealth 12: 513-518. https://doi.org/10.1007/s10393$\underline{015-1035-2}$

27. Herrera R.A., Steciow M.M. \& Natale G.S. (2005). Chytrid fungus parasitizing the wild amphibian Leptodactylus ocellatus (Anura: Leptodactylidae) in Argentina. Diseases of Aquatic Organisms 64: 247-252. https://doi.org/10.3354/dao064247

28. MurRay K.A., Retallick R.W.R., Puschendorf R., SKerRat L.F., Rosauer D., McCallum H.I., Berger L., Speare R. \& VAN Der Walt J. (2011). Assessing spatial patterns of disease risk to biodiversity: implications for the management of the amphibian pathogen, Batrachochytrium dendrobatidis. Journal of Applied Ecology 48 (1): 163-173. https://doi.org/10.1111/j.13652664.2010.01890.x

29. PicCo A.M. \& COLLINS J.P. (2008). Amphibian commerce as a likely source of pathogen pollution. Conservation Biology 22: 1582-1589. https://doi.org/10.1111/j.1523-1739.2008.01025.x

Manuscript received: 3 November 2016

Manuscript accepted: 3 May 2017

Published on: 1 August 2017

Branch editor: Merlijn Jocqué 